\title{
Great Expectations: Geological Theories and Technological Transfer at Aardal Copperworks in Norway in the First Half of the Eighteenth Century
}

Finn Erhard Johannessen, Professor of History, University of Oslo.

Institute for Archeology, Conservation and History, P O Box 1008 Blindern,

NO-0315 Oslo, Norway.

f.e.johannessen@iakh.uio.no

$+4722856853$

$+4790233383$

Words: 9487

Characters with spaces: 57383

Disclosure statement

I will have no financial interest or benefits arising from the application of my research.

Oslo, May 8. Finn Erhard Johannessen 


\title{
Great Expectations: Geological Theories and Technological Transfer at Aardal Copperworks in Norway in the First Half of the Eighteenth Century
}

\begin{abstract}
Aardal Copperworks in Western Norway were a small royally owned copperworks that operated at an enormous loss during the first decades of the eighteenth century. When the king did not close it down after short time, he had to choose between two options: Trust the director who, based on certain geological theories, predicted that large supplies of copper and other metals were to be found further down in the mountains or lease the copperworks to English interests who would introduce modern smelting technology based on coal. The king chose the first and his successor or rather the treasury the second. Both were unsuccessful, and Aardal Copperworks only became a minor episode in Norwegian mining history - but none-the-less included spectacular ideas, boundless optimism, extraordinary efforts and a tough reality.
\end{abstract}

Keywords: Mining, copper, coal, Paracelsus, alchemy, reverberatory furnace.

\section{Introduction}

On 17 August 1715, a man from London of Norwegian origin, called John Mathows, arrived in Aardal in Western Norway after having sailed alone from Bergen and into the $204 \mathrm{~km}$ long Sognefjord. ${ }^{1}$ He approached the director of Aardal Copperworks, Johann Heinrich von Schört, who took him up to the highest situated mines - Mathows had seen the lower mines the year before.

Mathows was interested in leasing Aardal Copperworks for smelting with coal in a reverberatory oven which was a quite new technology in Britain and had never been tried in Norway. Von Schört, however, wanted to continue in charge and extract the enormous values that existed in the mountains according to his theories - theories which could be traced two hundred years back in time.

This was therefore not only a meeting between two future rivals, but also between two historical epochs: the Industrial Revolution and the Renaissance. The rivalling projects and 
the way they were handled by the authorities is the theme of this article. It is introduced by a presentation on mining particularly of copper in Norway and to some extent in Sweden with a view on the situation in Britain.

\section{Mining in Norway in comparative perspective}

The mining industry was introduced to Norway in the sixteenth century. Ironworks, silverworks and later copperworks were established with privileges granted by the king. The ore in the ground was regarded as a royal regale. ${ }^{2}$ However, the original finder of the ore, independent of who owned the ground, could be expected to be given the right to start mining the ore and would be given privileges. These would ensure him exclusive right to the ore and also important rights in the area around the mine.

In Britain the situation was different: only gold and silver were considered a regale. ${ }^{3}$ Other metals belonged to the owner of the ground. Privileges were initially given also in Britain, particularly monopoly rights. Two large copper companies received such rights at the beginning of the seventeenth century, but they were abolished after the Restauration. ${ }^{4}$ From then on the British mining and smelting industry was a fully market-based activity.

In the Norwegian privileged system the term circumference is essential. ${ }^{5}$ This was originally a circle drawn with a radius of four Norwegian miles $(45 \mathrm{~km})$ from the smelting hut, later it often was somewhat smaller according to the local conditions. Within this circumference, the metal works were entitled to use the forests against pay, and even to command the peasants to perform transport services and deliver wood and coal against reasonable pay.

The circumference was a peculiarly Norwegian institution dating from the early seventeenth century, and it is reasonable to link it to the status of the Norwegian peasants. The peasants owned the farms themselves or were tenants, but they did not owe services to noble manors, which, with few exceptions, did not exist. Therefore the king could take control of the peasants' labour without running into conflict with the nobility. This was not possible in Sweden, for example, where manors were more common. Also in Sweden was peasant labour important for the metal works, but the peasants had to be recruited somewhat differently. 
The circumference must be seen as a mercantilist measure; the towns, too, were given circumferences granting the merchants local trading monopolies. The king had good reasons to support the metal works. They payed tenth and customs, and some of the products from the iron works had military importance.

The mining industry was from outset closely connected to Germany: the Norwegian mining law of 1539 was based on a Saxon mining law, and German experts and skilled workers were used from the start and well into the eighteenth century. There existed a parallel in Britain as companies from Tyrol and Augsburg were used for developing the British copper industry in the second part of the sixteenth century. ${ }^{6}$ They provided capital, experts and skilled workers. Their activity was, however, stopped by the Civil War, and most of the German workers were actually killed. The British copper industry also faced competition from abroad. Swedish copper was imported, and in 1680 a British copper mine was actually closed down due to the low price on Swedish copper. ${ }^{7}$

In the eighteenth century, Norway had 12-13 family-owned ironworks, mainly situated in the South-East, 4-5 copperworks owned by shareholders, and a single major silverworks, the royally owned one at Kongsberg in Eastern Norway. ${ }^{8}$ Most of the Norwegian copperworks were founded in the middle of the seventeenth century and were situated in mountainous regions not far from Trondheim in Central Norway. It was the leading merchants in Trondheim who owned the shares in the copperworks, and they took care of the export.

The metal works were generally located close to the deposits of ore, but with one exception: the ironworks, which were mainly situated in South-East Norway near forests that could provide charcoal, often received their iron ore from far away mines along the coast further south. This can be explained by the low cost of sea transport, which was also made profitable by the very high metal concentration in iron ore of up to 50 per cent (in contrast to silver- and copper ore, which each contain only a few per cent).

In total, the mining sector employed around 7000 miners during the mid-eighteenth century (while the total population in Norway was around 700,000), with the Kongsberg Silverworks alone employing some 4000 men during its peak around 1770. In addition a large numbers of peasants contributed, usually in winter as snow and ice made transport with horse and sled easy. 
The silver was used to make coins for the kingdom of Denmark-Norway, which at that time was united under one king and government in Copenhagen, while iron was used to produce military material as well as ovens and household utensils for the Norwegian and Danish markets. It was copper that was the export article.

Most of the copper was sold to Amsterdam, which was the center of the copper trade in Europe. Sweden, which produced less silver but more iron and in particular more copper, was the biggest copper producer in Europe in the seventeenth century with an average annual production of around 2000 tonnes in the second half of the seventeenth century. ${ }^{9}$ The Swedish production fell at the turn of the century, and was in average around 800 tonnes per year in the eighteenth century - almost twice the Norwegian production. ${ }^{10}$

In the Norwegian and Swedish mines ore was extracted by fire setting - burning of fires causing the solid rock to crack. But blasting with gunpowder had been introduced in the middle of the seventeenth century and was taken into use in this and the next century where forests were lacking or transportation was particularly difficult. ${ }^{11}$ The last applied to Aardal Copperworks where gunpowder was used.

Smelting was done in ovens where ore and charcoal were mixed and oxygen supplied from water-powered bellows. Smelting of copper was a particular long process with roasting and smelting two times and a final refining. In Aardal the first roasting was not applied as the ore contained less sulfur than usual (but it was noticed that the ore was hard to smelt). Wood and charcoal in big quantities were needed to smelting and roasting. That was a problem at many metal works, and the production of metal was often dependent on the volume of charcoal and wood that was available. That was particularly the case at the largest copperworks, Røros (today a world heritage site), situated as it was 600 meter above sea level and with harsh conditions for forests. ${ }^{12}$

Lack of forests had been a huge problem in Britain, and the transition to coal in metal smelting is usually seen as the start of the Industrial Revolution. In copper smelting this transition happened around thirty years earlier than in iron smelting. Smelting with coal was first demonstrated in the Bristol region in the 1680s with the use of the reverberatory furnace. ${ }^{13}$ In this furnace metal was smelted without direct contact with coal, because that 
would cause negative chemical reactions. From then on the copper industry drifted into Wales and to the Swansea valley which had huge supplies of coal while the copper ore could easily be shipped from the mines in Cornwall. This meant that Swansea during the eighteenth century took over the position from Scandinavia as Europe's leading producer of copper. ${ }^{14}$ The development accelerated in the nineteenth century. Tariff restrictions had limited the copper industry to using ore from Britain and Ireland, but as these were altered around 1830 the copper industry quite suddenly turned global and imported ore from Latin -America and a decade later from Australia.

\section{The beginning in Aardal}

Copper ore was first found at the top of a peak 1500 meter above sea level in Aardal in 1700 by two peasants who were hunting reindeer. Apart from the high altitude such findings were not unusual and had led to the establishment of several copperworks and the only large silverworks in Norway. Optimism was great, and investing in mining very popular. However, usually the deposits were meagre and small, and fortunes were lost and not made.

In Aardal private entrepreneurs soon started to extract the ore. Some specimens of pure gold were found among the ore, which is not unusual, and aroused the interest of the DanoNorwegian king, Frederick IV. A commission was appointed to gauge the deposit of ore, particularly the gold, and their conclusion was highly optimistic: in addition to future finds of specimens the commission expected that gold could be extracted in the smelting of copper ore. ${ }^{15}$ The last prediction was far from realistic. The gold content in copper ore was normally very small and could not be extracted profitably in Norway and hardly in Europe in preindustrial time. However, the king was guy and flame and decided to acquire the copperworks in 1708 for 37,600 daler, which was regarded as a huge sum of money (it equaled the value of three fully equipped frigates or 10,000 cows). The commission wrote that the copperworks could fall to the king as a regale, but he wanted to pay for it. ${ }^{16}$

It is by no means surprising that Frederick IV was attracted by the gold in Aardal. He had previously shown considerable interest in both gold and the art of making gold, or alchemy, which in fact was a wider term comprising an esoteric branch of chemical or pharmaceutical research. There was a strong tradition for such research in Denmark as in many other 
countries. The astronomer Tycho Brahe (1546-1601) was the most famous practitioner of alchemy in Danish history, and many of the kings shared his interest. ${ }^{17}$ Frederick IV, who had a furnace in his palace, even hired the Italian alchemist Grimaldy in 1708 - the same year as he bought Aardal Copperworks - to demonstrate his skills in making gold, and others followed later. ${ }^{18}$

Mining in the king's name started in Aardal in summer 1708, and after some months all the 60 miners who had earlier been working at the copperworks, were employed there. ${ }^{19}$ The idea was probably to produce copper with gold as an important by-product. In 1709 a smelting hut was built, and of the four men employed there, three were Germans who had earlier worked in a copperworks near Kristiania (modern-day Oslo) before making a short trip to Copenhagen to smelt ore from Aardal in the furnace at the king's palace.

Smelting began first the following year, in 1710, and from the start it became clear, as could be expected, that the gold content in the copper ore was so low that it was not profitable to extract it. Some specimens of gold were found, but not in sizeable quantities - the main rationale for the royal take-over seemed to have been proven wrong already from the start. At the same time, the amounts of copper-ore in the mines decreased. The ore was intercepted, the officials observed, and it was in fact a surface deposit. Activity was reduced accordingly, and in summer 1711 the copper-works was almost shut down. It seemed Aardal Copperworks would be rather short-lived as was indeed a common outcome in Norwegian mining. However, von Schört who arrived as a new director in the autumn created new optimism, and the royal mining which had started in 1708 continued until 1730 - though facing great challenges.

'It is well known now that in the whole of Europe no mines are situated and operated among so high cliffs and such a difficult mountain location as in Aardal,' Jens Worm wrote in 1733, and he was probably right (although some mines in the Alps may have been situated higher). ${ }^{20}$ Worm had been employed as a supervisor of the miners at Aardal Copperworks in 1708, after previously working in the same position at the silverworks at Kongsberg, and he advanced to storekeeper the same year.

Aardal copperworks were the only copperworks situated by the sea. It was surrounded by mountains, and the fjord was the only channel of communication with the outside world. 
However, in winter the inner part of the fjord was covered with ice which was usually thin and not safe for walking or using sled but at the same time prevented the use of boats. Therefore, in winter the copperworks were isolated for several months. In the autumn the copper had to be shipped to the closest town, Bergen, and supplies brought in before the fjord froze.

As the forests were situated on both sides of the fjord, the ice meant that the charcoal work had to be done in summer, not in winter as was common by the other metal works. The peasants actually had to deliver wood, and not charcoal, that was processed to charcoal close to the smelting hut - because loading and unloading of charcoal during a long transport would have reduced the quality of the material.

The highest mines were situated at the top of the mountain 1500 meters above sea level where ore first was found. Here the ground was without vegetation and was covered with snow except for three months in summer. The four-hour long walk uphill was so hard that it felt like soul and body should separate, Worm noticed. ${ }^{21}$ During the week the miners lived in a house at the top of the mountain close to the mines before going down to their families on Fridays. The weather sometimes made it impossible to leave the house to go to work in the nearby mines.

The miners were perfect skiers, Worm noted, but it happened every winter that they had to return on their way up because of bad weather. ${ }^{22}$ Sometimes miners fell and were injured, and one time two men were taken by surprise by a storm and had to dig into the snow for the night. The ore was taken down in winter by peasants with horses that went on snowshoes except from the lower mines situated in a steep cliff closer to the smelting hut 500 meter above sea level where more friction was needed.

The most fascinating example on making use of the extraordinary natural environment was found in the building of the highest situated mines where ice was used instead of props: in the autumn, water was led into the mines - which went vertically down in the ground - and after some time a thick layer of ice formed and the water was pumped out from underneath the ice. This both strengthened the mines and was a practical floor for the workers (holes were made for shafts and ladders). The icy construction also kept its strength during summer. Ice-floors could be made in two or three layers and aroused great interest in visitors. 
A commission that visited Aardal Copperworks in 1720 observed two layers of ice, three or four years old, in the middle of one of the mines, 'which', as they put it, 'can be regarded as rather odd'. ${ }^{23}$ Another commission that studied the then abandoned copperworks in 1743 wrote about the method in the spirit of the Enlightenment: 'This demonstrates a peculiar way of building mines, and in addition shows that nothing in nature is without reason, as it has even been possible to utilize the cold air, no matter how disagreeable it may be at the apex of this wild mountain'. ${ }^{24}$

Such efforts and creativity were, however, poorly rewarded. The very first years were the most productive period, but from then on output steadily declined. From 1708 to 1730 the total production was 109 tonnes of refined copper, or in average around 5 tonnes a year, which was a record low in Norway. The sale of copper covered 41 per cent of the total costs, and public subsidies the remaining 59 per cent. ${ }^{25}$ So why was all this money wasted? It is time to return to Johann Heinrich von Schört.

\section{A theoretician in charge}

Von Schört was born in 1660 in Kassel, then the capital of the German landgraviate of HesseKassel as the son of Brostrup von Schört who would later work as a mining official in Norway. ${ }^{26}$ The younger von Schört received military training but also some mining education in the important German mining area Harz. (Worm once mentioned the saying: "14 crafts 15 accidents", suggesting that von Schört only knew his disciplines superficially which could be disastrous). ${ }^{27}$ Later he worked as an officer, interrupted by some periods as a mining official in Clausthal and Hesse. After several years of unemployment he decided to go into Danish service in 1709 when Denmark-Norway attacked Sweden in alliance with Russia and Saxony during the Great Northern War (1700-1721). In March 1711 von Schört was appointed as lieutenant-colonel in the artillery in Denmark, and some months later he was appointed as director of Aardal Copperworks because of his mining experience (no director had been appointed after the royal take-over in 1708).

Von Schört took over a copperworks in crisis. The ore had disappeared, most of the mines were closed down and many of the miners had been fired. Von Schört, however, was not 
discouraged. He inspected the mines with the other officials and concluded that the dearth of ore was only temporary. He therefore reopened the mines, and after a few months all the miners were back at work.

Von Schört was keenly interested in what he thought were rich pickings of gold. The gold content in the ore could be extracted profitably if the best method, the Hungarian one, was used, he claimed. A quarter of a pound (117 gram), probably more, could be extracted from a barrel of ore. ${ }^{28}$ In 1713 von Schört forecast a future annual production of copper of around 64 -80 tonnes, and the following year he announced that the mountains in Aardal were full of ore and that several smelting huts would be needed.

What was the basis for his optimism? The other officials wrote that von Schört used what would now be called a comparative method where he presumed that conditions in Aardal were similar to what he knew from other places in Europe. ${ }^{29}$ This becomes evident when we study von Schört's letters, where he made frequent comparisons with German and Hungarian mines, by drawing on his extensive reading of various foreign books on mining.

From a comparison with St. Annaberg in Saxony, von Schört concluded that the mountain where the lower mines were situated, consisted of layers. At the top was a layer of cobaltlead, followed by layers of tin, copper, silver and gold. He regarded the fog that was often seen above this and other nearby mountains, as wittringer (from German Witterungen), a sign that they contained metal. Von Schört could thus stand by his house and tell where in the mountains ore was to be found. ${ }^{30}$

Von Schört's fundamental idea was that metals and minerals ascended and concentrated at the highest points on Earth like the Gotthartsberg in Switzerland. He called such a point a promontorium or a centrum metallicum. Horrungene, one of Norway's most alpine regions and today highly popular for climbing, is situated very close to Aardal with peaks up to 2400 metres above sea level. Here a centrum metallicum was to be found, according to von Schört, and the ore in Aardal belonged to its western side.

In September 1713 von Schört actually sent six miners led by a supervisor of German origin to Horrungene for prospecting. This appears to have been a rather shocking experience, with the supervisor writing that Horrungene was a frighteningly high mountain, covered with a 
glacier which was dangerous to enter because of deep fissures (that can be tried out even today). He reported that the cold was so terrible that the men would soon have died if left there. The prospectors took some samples of ore and returned the second day. ${ }^{31}$

The historian of science Rachel Laudan has noted how, far into the nineteenth century, prospecting remained a pragmatic and largely unscientific endeavor, one where

'(P)rospectors relied on the time-honored methods of following surface deposits underground, examining hillsides after rain to see if unusual deposits had been exposed, tasting spring water for unusual metallic tastes, running trial sinkings and borings, and (most dubious) using the divining rod. ${ }^{32}$

The pragmatic attitude had been followed in the first years in Aardal. When the ore seemed to disappear or be intercepted, mines were closed and activity reduced as per the standard mode of operation. Von Schört's approach was different, however: he was a theoretician. The question then is, where had he found his ideas?

After his death in 1720 von Schört's belongings were registered, and among them were 96 books and manuscripts mainly on mining and military affairs, besides Euclid's introduction to geometry. ${ }^{33}$ The mining literature included well-known books like Georg Agricola's famous De re metallica and Johannes Mathesius' Sarepta oder Berg-Postill, both from the sixteenth century, and Balthasar Rössler's Berg-Bau-Spiegel from 1700, Abraham von Schönberg's Ausführliche Berg-Information from 1693 and several books on assaying. Notably, the list also included the works in two volumes of Theophrastus von Hohenheim, called Paracelsus. In his letters von Schört quoted Paracelsus several times, and it is clear that he was deeply influenced by his ideas.

Paracelsus was born in Switzerland in 1493 and became a highly influential thinker and occultist during the Renaissance. ${ }^{34} \mathrm{He}$ did not write much himself, and it was his pupils and followers who published the volumes with his ideas and their own elaborations, thus establishing the Paracelsian tradition.

Like many of the Renaissance-thinkers Paracelsus was a Christian Neoplatonist. He had a spiritualistic worldview where some sort of unity existed between God and the wider 
universe, or macrocosm, and every human being, or microcosm. He was much concerned with medicine and became influential in his use of chemicals, like various metals, in healing, a practice that mirrored his use of chemicals for transmutation, that is the transformation of one substance into another - such as base metals into gold.

Typical for Paracelsus, and more generally, for the scientific revolution in the seventeenth century, was the mixture of ground-breaking ideas and failures developed from old notions, and it is therefore not surprising that even a scientific giant like Isaac Newton also took a great interest in alchemy. Von Schört was obviously a learned man, irrespective of whether his ideas appear outlandish to modern scientific standards.

Archeus was a key notion in the Paracelsian tradition, and was also referred to by von Schört. ${ }^{35}$ This was a sort of life force that was 'inherent in all seeds be they animal, vegetable, or mineral', as the American historian of science Allan Debus puts it. ${ }^{36}$ This means that minerals were seen as living things, and that they developed like plants in earth. Comparisons between the origin of minerals and human conception and birth also existed. After being conceived in the interior of the Earth, the minerals grew and finally reached the surface, and while they grew, they developed from base to more perfect metals. ${ }^{37}$ This explains von Schört's theory of layers of metals in the mountains.

There existed similar theories, but they lacked the Archeus dimension. In Geologia Norvegica, the first book on Norwegian geology from 1657 (and subsequently translated to English in 1663), the making of minerals is explained in somewhat more materialistic terms. ${ }^{38}$ When any dry substance in and under the earth was mixed with wet or moist substances and exposed to the influence of the planets, or to subterraneous fire and warm waters, minerals were produced. When the minerals were perfectly boiled and wrought below in the earth, they sprang up in cliffs or holes in rocks.

Geologica Norvegica did not include any development from base to more advanced minerals, but in Balthasar Rössler's Berg-Bau Spiegel, which belonged to von Schört's library, it was mentioned that this took place deep in the Earth. ${ }^{39}$ The aforementioned phenomenon wittringer or Witterungen, fog as sign of metals, was also explained in this book. ${ }^{40}$ This was steam shining like fire which sometimes emanated from particularly rich deposits of ore. The same explanation is found in Abraham von Schönberg's Ausführliche Berg-Information. ${ }^{41}$ 
I have not found von Schört's theory of centrum metallicum in the literature, and it was probably an idea he had developed himself. An anonymous and undated handwritten manuscript which had belonged to von Schört, Manu Script von bergwergken, actually exists today in the public library in Oslo which origin was a collection of books from the eighteenth century. ${ }^{42}$ This manuscript is entirely based on Paracelcian ideas, and the term centrum where minerals came up, is mentioned frequently. Von Schört made a lot of underlining and comments in the margins. He even wrote promontorium (which he used synonymous with centrum metallicum) where the word hoch (high) was mentioned. During these studies, von Schört probably developed the theory of centrum metallicum being located at the highest places. The theory can be seen as an extension on the idea of mineral's regeneration. As minerals improved while ascending, it seemed quite logical that they had reached the greater state of perfection when they showed up at the highest points on earth.

The theory was also applied to the Jostedal Glacier, the largest glacier in continental Europe, situated quite close to Aardal. Von Schört believed, falsely, that the glacier reached much higher than Horrungene and drew the logical conclusion that even more valuable deposits were to be found there. The argument was strengthened by an assertion from Paracelsus about a vast treasure that supposedly existed in the Nordic region between the 60th and 70th parallels. Von Schört believed that part of the treasure was to be found under the glacier - a possibility Paracelsus had not considered, he added. ${ }^{43}$

Von Schört's optimism regarding the ore in Aardal was conveyed in his letters to Copenhagen. Some of them were addressed directly to Frederick IV, and there is all reason to believe that the king was receptive, given his above-mentioned interest in alchemy. Denmark-Norway was an absolutist monarchy, but that does not necessarily mean that the kings were omnipotent, and several left decisions to their advisors. Frederick IV, however, was the most able Danish-Norwegian king in the eighteenth century. He was hard-working and made his decisions with the counsel of his cabinet, but with two exceptions: in military and economic affairs he made the decisions himself, only accompanied by his secretary, who wrote them down. ${ }^{44}$ That means that influencing the king, as von Schört obviously did, was important, not to say decisive. 
However, was von Schört sincere or fraudulent? Had he merely found an easy method for tapping money from the king? That is a difficult question to answer. Most of von Schört's ideas were quite common, and his letters were full of extensive quotations from various mining books. It is hard to imagine that he did not believe in the ideas himself. On the other hand, Jens Worm once commented on the director's optimistic letters in his first years, where von Schört once allegedly said that Worm and the other officials should not worry over subsistence, neither for themselves nor for the copperworks, as he would present the situation to the king in such a way that 'his teeth would water'. ${ }^{45}$ This can be interpreted that von Schört was just bluffing, or, as I find more likely, that he was exaggerating his optimism and estimates in order to pursue his own vision.

We don't know if contact between von Schört and Frederick IV started with the letters from Aardal. It is not improbable that the king had known about von Schört before that, and that the mining expert was transferred from the artillery to Aardal Copperworks in 1711 in order to improve the deteriorating situation there.

What sort of a role did von Schört play? Although employed by the king, he was not at all a typical (and loyal) manager like his opponent and successor Jens Worm. Apparently he had more in common with an entrepreneur in the wider meaning as a person who on the basis of his or other's ideas is able to make an innovation which can be anything from a product, to a process or a method etc. What can be interpreted as von Schört's innovation, was a method. He had wide knowledge of geology and mineralogy of a general kind, but was the only known person who tried to use this for prospecting (in a very ambitious way). This can be called theoretical prospecting in contrast to the current empirical methods. Von Schört also had power, energy, imagination and ability to attract money from investors, qualities often associated with entrepreneurs.

The importance of knowledge for the industrial revolution in Britain has recently been underlined by Joel Mokyr, who has proposed the term "Industrial Enlightenment". ${ }^{46}$ The problem in Aardal was that von Schört's method was based on false pre-Enlightenment knowledge. Von Schört was never accused of this, the question rather seems to have been if he had useful knowledge - or useless. 
After his arrival in 1711 von Schört started up in great style. Major construction work was initiated in some of the mines, and von Schört built several houses, both for production purposes and as residential houses for the officials. He even built a large house for the king and his company, believing that a royal visit was possible.

Production fell, however, and subsidies were needed, leading to a big debt to merchants in Bergen being accumulated. The treasury had had enough, and in a proposal which the king passed in March 1714 it was made clear that the operation should not continue in the same way: the copperworks should be allowed to sell its large stock of copper, but receive no more subsidies, and in the future the director should to some degree be controlled by the lower officials. ${ }^{47}$ This reorganization did not improve relations between them - in 1718 Worm complained that von Schört did not follow the instructions, and when he was reproached, he became as though insane and immediately threatened to stab, slash and shoot them. ${ }^{48}$

The first years after March 1714 went quite well, thanks to the sale of a large stock of copper, but production was low, and from 1717 the copperworks again fell into debt. It was impossible to pay full wages to the employees, and many were made redundant. It was obvious that it was impossible to run the copperworks without subsidies, and discussions about the future, which were to last for two years, started. The starting point was a surprising offer from England.

\section{New technology and new expectations}

As mentioned introductory in 1714 and 1715 the English visitor John Mathows arrived in Aardal wanting to see the copperworks. His ideas about Aardal Copperworks were probably less theoretical and more industrial and modern than von Schört's. What they had in common was their expectations: Mathows had said, according to von Schört, that the copperworks should have been run with around a thousand men which would have provided an annual surplus of thousands of pound sterling. ${ }^{49}$ This must mean that he also believed that huge amounts of ore were concealed in the mountains of Aardal. Probably Mathows was a victim of rumours emanating from von Schört's optimistic reports to Copenhagen. 
In 1717 Mathows wrote to the treasury and proposed leasing Aardal Copperworks for 20 years. He wanted to smelt the best ore in Aardal, while the poorest was be exported to England and smelted there. Mathows would pay 1000 daler as an annual fee as well as 1000 daler annualy instead of toll and tithes. He wanted further to smelt with coal, not charcoal, and that made the offer quite sensational: The British copper industry which had been inferior to the Scandinavian, particularly the Swedish industry, had introduced new technology in the last decades of the seventeenth century, moved ahead and now made an effort to expand into Scandinavia. The pre-industrial Norwegian mining industry had been solely dependent on German technology, and technology transfer from Britain was first to become important during Norway's industrialization from the 1840s. ${ }^{50}$

As can be imagined the treasury was fired up about Mathows' offer. It seemed possible to get a fixed annual income instead of paying out subsidies, and at the same time acquire valuable new smelting technology. Von Schört had actually, based on Mathows' description, made a drawing of the reverberatory furnace, which had not been used in Norway at that time, and sent it to Copenhagen, probably because it was interesting new technology.

A draft for a contract with Mathows was made, and it was approved by Frederick IV with the exception of three crucial points: the copperworks should be leased to Mathows only for 10, not 20 years, all the ore was be smelted in Norway and the annual fee was to be 3000, not 2000 daler. $^{51}$

The first and third points suggest that the king had maintained his belief in the resources to be found in the mountains in Aardal, a belief that was probably strengthened by the Englishman's interest. The second point probably reflected mercantilist scepticism against the export of raw materials. Danish-Norwegian mercantilism focused primarily production, and manufacture was supported by tariffs or prohibition on import. ${ }^{52}$ Similarly export of raw materials that could be manufactured domestically was forbidden or charged with high tariffs, and here metals were a case in point. Export of ore had probably not been an option earlier, but it follows from this thinking that it should be processed domestically as much as possible.

For his part, Mathows rejected the conditions to his offer, but kept in touch with the treasury. As a result, comprehensive discussions about the future of Aardal Copperworks took place over the following two years. A conference was held in Copenhagen, and new actors like the 
Oberbergamt, the central mining authority in Norway, were consulted. Oberbergamt was positive to leasing the copperworks to John Mathows, and the treasury also strongly advocated this.

Von Schört, however, was fiercely opposed to the contract with Mathows, stating that it was too favourable to Mathows and that strong (mercantilist) arguments spoke against the export of ore - not only was profit from the smelting thereby lost, he explained, but metal or money left the country and found its way to another nation. ${ }^{53}$

He repeated all his optimistic ideas about the possibilities in Aardal, including the high gold content of the copper ore, and added that gold would be found below the copper ore. He suggested operating the copperworks on a large scale and making two large adits (i.e. galleries from the surface into the mountain) to open up the treasures in the ground. Apparently, von Schört wanted to access the centrum metallicum directly.

Jens Worm, who also took part in the conference in Copenhagen, wrote quite frankly that the director opposed leasing because he was afraid of losing his job. Worm admitted that exporting ore was in principle against the king's interests, but not in this case, and supported the lease of the copperworks with the following arguments: the copperworks operated with huge deficits, it had accrued debts, the mines were meagre and it would be exorbitantly expensive to find out how much ore there was further down. Worm commented that von Schört's optimism and projects always had highly long-term perspectives, wryly noting that: 'in the meantime either the man or the horse dies'. ${ }^{54}$ Worm's opinion was that it would be best to lease out the copperworks, or even better sell it.

Probably inspired by Worm's arguments, von Schört finally came up with an idea of dividing the copperworks into 128 parts that could be sold for 1000 daler each. ${ }^{55}$ That meant selling the copperworks for 128,000 daler, which was an enormous sum. In a proposal to the king in spring 1719 , the treasury characterized this idea as highly unrealistic and wanted to carry out the lease to John Mathows, who had retained his interest. But the treasury lost the argument, and von Schört's idea was accepted in the king's resolution. This entails that the king still had faith in von Schört and his ideas about the valuable resources to be found in Aardal. 
Almost as soon as von Schört was back in Aardal, he wrote about a new and very promising deposit that had been found near the highest mines. Worm confirmed this and mentioned that it had been found when he and the director had been in Copenhagen. Some weeks later von Schört wrote that the new deposit had a value of 73.5 million daler. ${ }^{56}$ This was based on an estimation of both content and volume (one foot wide, 8000 metres long and 600 metres deep). The treasury was sceptical, particularly wondering how von Schört could know that the ore continued so far down, but the king was more enthusiastic and cancelled the sale of the copperworks - now he wanted to run it himself. ${ }^{57}$ That may well have been von Schört's intention, though it would also be his final triumph, as he died a few months later, in February 1720, after a short illness.

Worm took over as head of the copperworks with the title of inspector. Each year the copperworks received sufficient subsidies, around 4000 daler, and could be run in a stable manner with around 40 men. As Aardal Copperworks was quite small, this was not an excessive amount of money for the state, and that helps to explain how the activity could continue for another ten years. The fact that Kongsberg Silverworks, the behemoth of the Norwegian mining sector, received at the time an average of 25,000 daler in annual subsidies puts the subsidies paid to Aardal Copperworks in perspective. ${ }^{58}$

The new deposit turned out to be a great disappointment, but in 1723 a new hope was lit. Ore was found in a new area, and it was particularly rich, as also confirmed by a modern geological survey. ${ }^{59}$ In September Worm wrote that rumours about a great capital having been extracted from the new deposit had spread far and wide throughout the country. The new deposit was situated further east than the other mining areas, closer to Horrungene. Perhaps the centrum metallicum had finally been found? Mines were made, but soon the amount of ore decreased, as it had always done. Nevertheless, the mines were operated until 1730.

Negotiations with John Mathows and later his son in law and a new English group continued after the death of von Schört, and an agreement on a ten-year lease was reached. ${ }^{60}$ However, it came to nothing due to embezzlement in the English group. Finally, in late 1729, a new Englishman, Francis Grant, showed interest, and together with his associates (one of them with a connection to the Temple Mills Brass Works) he sought to buy or lease Aardal Copperworks. After some correspondence, it turned out that Grant was most interested in leasing the works for 21 years, for which he would pay 5000 daler a year and be allowed to 
export as much ore as he wanted. But the best ore was to be smelted in Aardal. ${ }^{61}$ The following summer two representatives, John Hamilton and James Hellewell, visited Aardal to inspect the site on behalf of Grant.

Grant himself was operating in cooperation with or on behalf of a company called 'the Charitable Corporation'. This is one of the more notorious companies in British business history. ${ }^{62}$ It was established by a charter in 1707 and seems to have started business in London in 1719. The idea was that small tradesmen might obtain loans by deposing a pledge in the corporation's warehouse when suffering cash flow difficulties. However, it turned out that the borrowers had to pay not only interest but also fees that gave the company more than 'lawful interest'. In addition the directors or partners started to speculate with money borrowed from the company on false pledges. In 1730, concurrent with their interest in Aardal, the company had also invested in mines in Scotland, and the next year the whole construction collapsed, leading to two of the partners being declared bankrupt after having tried to escape to France and to ruin for a lot of people - half of those not undone by the South Sea Bubble ten years earlier, it was said.

It was therefore a rather dubious company in England which had shown interest in a highly unprofitable copperworks in Norway. But what was behind the attraction? Why were Englishmen constantly interested in these copperworks which were well known for their great losses?

In a letter from July 1730 when he had just received the two representatives from the English company, Jens Worm commented upon this very matter. ${ }^{63}$ He explained that it was a common view that the reason for the losses was that the copperworks had been operated with too few people and too little money (as John Mathows also had said according to von Schört). This common view was shared by the Englishmen, both the present and the previous visitors (and Worm had certainly done his best to encourage such views) which must mean that they believed the mountains were full of ore. Worm made it clear to the treasury, however, that this view was completely wrong. Greater efforts would have meant greater loss.

In his letter Worm also commented on the question of exporting ore and mentioned that Hellewell was ostensibly a man of 'extraordinary sciences'. Hellewell wanted the ore from Aardal to be processed at a smeltery in England, as now was done with ore from America. 
The last comment is interesting. Worm probably referred to ore from New Jersey which was exported to England in the period 1720-1750. ${ }^{64}$ This export can be seen as anticipating the globalization of the copper industry that took place around hundred years later, and is neatly explained by British America not being exposed to the prohibiting tariff restrictions as the other producers oversea at that time.

As Worm understood Hellewell, export of ore was essential for any agreement to be made, and such an arrangement was, in his opinion, not at all contrary to the king's interest. Worm also stressed that it would be an advantage to introduce the new smelting method with coal in Norway as it was far better than smelting with charcoal.

In July 1730 the treasury recommended to Frederick IV that he should accept leasing Aardal Copperworks to Grant for 21 years with the right to export as much ore as he wanted against an annual fee of 5000 daler. ${ }^{65}$ But what would the king, who had shown such obstinate resistance against long-term lease agreements and the export of ore, say? The answer is: he said nothing as he fell ill in that same month and died in October. His son, Christian VI, accepted the proposal immediately, and the contract was signed by him and the partners of the Charitable Corporation: Archibald Grant, William Burroughs, William Squire, John Thompson and Georg Robinson. ${ }^{66}$

The treasury had finally put an end, at least temporally, to a public loss-maker, and exciting new technology was about to be introduced to Norway. Only one effort on smelting with coal had been made in Norway a few years earlier, but that had been rather unsuccessful. At the same time Norwegian ore was to be exported to England for smelting there, a first in Norwegian history - foreshadowing Norway's role as a supplier of ore or half-processed metals in the modern era.

In late July 1731, James Hellewell, as representative for the leasers, arrived in Aardal, followed soon after by a ship with skilled English workers (probably from Newcastle, as wives there were later mentioned), materials and coal. Jens Worm left Aardal to take up a position in the mining administration in Trondheim, and a new inspector, Johan Dahl, was appointed to take care of the new king's interests in Aardal. Under Hellewell's leadership, the mining work continued, and he tore down the smelting hut and built a stamp mill at the same 
spot. Some ore was sent to Bergen and shipped to Newcastle for smelting there, but that was soon stopped as being unprofitable. ${ }^{67}$

In Aardal preparations seemed to be going fine when, around Christmas, the treasury received a letter from the Charitable Corporation's business connection in Copenhagen with unpleasant news: two of the partners (in fact, Thompson and Robinson) had reportedly absconded from England with a good deal of the company's money. The company therefore was bankrupt and unable to continue its activity in Aardal. ${ }^{68}$

Hellewell wanted to find new investors and received a deferral on his interest payment and even some additional credit. In 1732 he travelled abroad, in England and France, according to what he wrote. In a letter to the treasury in November 1732, sent from Copenhagen, he wrote that he had met investors in Paris who would take over the copperworks, but he needed credit for another six months. ${ }^{69}$ The treasury noted in its counterproposal that Hellewell was unable to provide security for the credit and that the king had suffered more than enough losses. On the other hand, it was not wise to stop Hellewell before the new smelting method had been introduced, as it might prove highly advantageous both to Aardal and to the other copperworks in Norway. The treasury therefore recommended that Hellewell received credit, and that was accepted by the king. ${ }^{70}$ Nothing more was mentioned about the investors in Paris.

In winter 1733 Hellewell was back in Aardal, and in spring the new reverberatory furnace was built. English brick, clay and sand were used. 'A new furnace is operating here now, thank God, and with it Mr Hellewell wants to show all Norway a masterpiece,' inspector Johan Dahl wrote in the middle of June. ${ }^{71}$ The construction was very different from the old furnace, Dahl continued, and the heat generation was formidable. From the chimney the flame reached almost two metres, which sounds probable as a barrel of coal had the same effect as ten barrels of charcoal. The furnace was therefore built with English materials which were particularly heat resistant.

It was not easy for Dahl to obtain more information about the furnace. He complained about the smelting being kept secret and that he rarely was permitted to enter the hut. As a result, he decided to do some sleuthing. He would sneak around, try to pump the workers for information and sometimes play a fool. In the end he was rewarded with the information he 
was looking for: the furnace was almost 4 metres long, and the smelting chamber which was 1.25 metres deep, was separated into two variously sized parts. Coal was placed in the smallest part, ore in the largest, and the flame passed over the ore on its way to the chimney. ${ }^{72}$

From Trondheim, the former inspector Jens Worm wrote asking if they had found a new smelting method that would be particularly useful in areas lacking forests. ${ }^{73}$ As mentioned earlier lack of timber and charcoal was a major problem at the largest copperworks. Unfortunately the great expectations failed again. In total, only about a tonne of copper was produced by Hellewell. It is well known that it was not easy to find the right mixture of ore for the smelting in the reverberatory furnaces to be successful, and in addition, as mentioned introductory the ore in Aardal was regarded as hard to smelt. Hence, it is not surprising that it was difficult to get the new furnace to work. This was probably the reason why the smelting at Aardal was so shrouded in secrecy - Hellewell did not want Dahl to inform the treasury about the difficulties. It did happen that Dahl was invited to the smelting hut, but that was when copper was to be tapped, and Hellewell could hope for a positive report to the treasury.

Indeed, an expert who made a report about the copperworks three years later characterized Hellewell's smelting as childish, writing that Hellewell probably had believed that the ore in Aardal was as easy to smelt as English lead or tin ore. ${ }^{74}$ However, a successful smelting would probably not have turned Aardal Copperworks into a profitable business either. The main problem was the lack of ore in the mines, not lack of energy.

Without effective smelting, the activities in Aardal gradually deteriorated, and the workers left the site in autumn 1733 and winter 1734. In response, the treasury appointed two men from Kongsberg Silverworks to examine the facilities, and they arrived in Aardal in late February 1734. One of their tasks was to make a test smelting to find out whether the new method was favourable. This was carried out in late March, and two men from Stora Kopparberget, the great copperworks in Sweden which faced problems with its charcoal supply, were present. ${ }^{75}$

The smelting, however, was not successful. The commission found that the value of the extracted copper was less than the cost of the consumed coal. Regarding the future of Aardal Copperworks, the commission was crystal-clear: there was no hope for profitable operations for the king if God would not make new deposits appear. The commission therefore 
recommended that the copperworks be offered to interested parties on very generous terms. Smelting with coal was not introduced in the Scandinavian copperworks before the end of the nineteenth century.

Hellewell left Aardal in summer 1734, and the copperworks were formally closed down. Activity was taken up again in the period 1756-1762 with minimal production and heavy losses. Later, almost until the present time, many plans about taking up mining in Aardal have been made, but not carried out. The Geological Survey of Norway (NGU) investigated the copper deposits in 1976/77, and the conclusion was that all known deposits in the area could be regarded as not commercially exploitable, and would probably never become so. ${ }^{76}$ But there was one exception, namely the third and final field found in 1723. As this field was nigh inaccessible, it had not been possible to obtain quality information, but enough promising samples had been found to allow a certain muted optimism.

Although Hellewell had been unsuccessful, his efforts received attention. That the new smelting method was regarded as important was demonstrated by the interest shown not only by the treasury and Worm but also by the largest Swedish copperworks. How unsuccessful the smelting method was can perhaps be discussed: it seems to have worked technically as some copper was produced, but to have been unsuccessful because the ore was inherently difficult to smelt. The technique might well have worked better at other sites or with other combinations of ore.

There exists a parallel in the efforts to introduce the British Newcomen steam engine to the Swedish ironworks at Dannemora at about the same time, 1726-1736. The engine worked in periods, but was unstable, and the Swedish historian Svante Lindqvist concludes that the introduction of the steam engine was a failure as the aims were not achieved. ${ }^{77}$ Lindqvist points to a number of reasons, including climatic, economic, social and cultural ones. One of the main problems, however, was technical: in England the pumps were made of cast iron, but no Swedish ironworks could manufacture such equipment, and the pumps were made from bored-out elm logs, which ultimately proved too weak.

This seems to have been a much more complex and difficult operation than introducing the reverberatory furnace in Aardal. Here the problem was not the domestic materials, as the 
furnace was built with English brick, clay and sand, but the domestic ore, which turned out to be difficult to smelt.

Parallel to Kristine Bruland's observations on the development of the Norwegian textile industry in the mid-nineteenth century it can be concluded that British technological experience in the field of pre-industrial metallurgy was not imitated, but extended to Norway. ${ }^{78}$ A possible further development was, however, interrupted by the subsequent British prohibition on export of machinery and skilled artisans - an interruption that lasted until the repeal in 1843 of the act forbidding the export of machinery. Norway's first phase of industrialization followed immediately.

\section{Conclusion}

The remote and isolated Aardal situated by the beginning of Norway's longest fjord and surrounded by huge mountains, was an odd place for the Renaissance and the Industrial Revolution to meet in the early eighteenth century. The man representing the Renaissance, von Schört, had been the most important figure for the mining venture in Aardal. Without him arriving in 1711, the copperworks would probably have been closed down the same year.

Von Schört's theories about the abundance of metal to be found in the Aardal mountains were based on ideas from the Renaissance thinker Paracelcus blended with ideas quite common in his own time. Unfortunately his ideas proved false. Von Schört's theorized centrum metallicum simply did not exist. However, the absolutist king who was interested in alchemy, believed in him, and the optimism was nurtured by the findings of new and promising deposits. Therefore the copperworks were not leased to English entrepreneurs as long as the king was alive.

These English entrepreneurs were probably not theoreticians at all. Joel Mokyr has, to be sure, underlined the importance of the Enlightenment for the industrial revolution but, like many others, he has also emphasised the importance of experience and practical knowledge particularly in fuel-based processes. ${ }^{79}$ In contrast to von Schört the English entrepreneurs were on the right track; introducing copper smelting with coal in Aardal successfully was not 
impossible. However, they could not have made an economic success as it was lack of ore which was the fundamental problem.

All the English entrepreneurs seem to have shared von Schört's optimism, and they had probably been taken with rumours caused by von Schört's optimistic reports to Copenhagen. Great expectations, whether they were based on theoretical (mis)understanding or not, seem to have been the fundamental and mutual factor for all involved. This is a general phenomenon in mining. Treasures in the deep and the possibility of making a fortune have always tempted man. As a commission that inspected the then abandoned Aardal copperworks in 1743 sagely noted: 'A miner's hope never rests, but chases all below into the eternal deep'. ${ }^{80}$

\section{Notes on contributor}

The author is a Professor in History at the University of Oslo. His main interests are economic and general history in early modern time.

\section{Acknowledgements}

I would like to thank Bjørn Ivar Berg at the Norwegian Mining Museum for important assistance with seventeenth-century mining literature, my colleague Klaus Nathaus for valuable comments to a draft and another colleague, Henrik Olav Mathiesen, for help with the English language.

\section{Notes}

\footnotetext{
${ }^{1}$ Letter from von Schiört 26 August 1715, the National Archives of Norway, Oslo (Rentekammeret, Realistisk ordnet avdeling, bergverksvesen, box 31).

${ }^{2}$ Helland. Norsk bergret. Med udsigt over andre landes bergvarkslovgivning, 1-13.

${ }^{3}$ Helland. Op. cit., 112-121.

${ }^{4}$ Hamilton. The English Brass and Copper Industries to 1800, 45-68.

${ }^{5}$ Berg, 'Plikt eller marked i jernverkenes trekullforsyning.'

${ }^{6}$ Hamilton. The English Brass and Copper Industries to 1800, 10-44.
} 
${ }^{7}$ Heckscher. Sveriges ekonomiske historia, 2.1, 449.

${ }^{8}$ Dyrvik, ed. Norsk $\emptyset$ konomisk historie 1500-1970, vol 1 1500-1850, 48-53, 169-175.

${ }^{9}$ Heckscher. Sveriges ekonomiska historia, 1.2. 444.

${ }^{10}$ Heckscher. Sveriges ekonomiska historia, 2.1. 369. Dyrvik, ed. Norsk фkonomisk historie, 52, 170.

${ }^{11}$ Berg. Gruveteknikk ved Kongsberg Sølvverk 1623-1914, vol 1, 73-91, 156-160, 168-169.

${ }^{12}$ Øisang. Røros kobberverks historie, 115-117, 131-136, 152-156.

${ }^{13} \mathrm{King}$, 'Sir Clement Clarke and the adoption of coal in metallurgy'.

${ }^{14}$ Newell, '"Copperopolis"': The rise and fall of the copper industry in the Swansea district, 1826-1921'. Evens and Sanders, 'A world of copper: globalizing the Industrial Revolution, 1830-70.'

${ }^{15}$ Johannessen, ‘Årdal Kobberverk', 11.

${ }^{16}$ Op. cit., 12.

${ }^{17}$ Fink-Jensen, 'Alchemy in Denmark', 11-12.

${ }^{18}$ Op.cit., 16.

${ }^{19}$ This and the following from Johannessen, ‘Årdal Kobberverk', 71-74.

${ }^{20}$ Jens Worm, quoted in Johannessen, ‘Årdal Kobberverk’, 25; all translations from this thesis into English are my own.

${ }^{21}$ Johannessen, ‘Årdal Kobberverk’, 27.

${ }^{22}$ Ibid.

${ }^{23}$ Johannessen, ‘Årdal Kobberverk’, 57.

${ }^{24}$ Ibid.

${ }^{25}$ Johannessen, ‘Årdal Kobberverk’, 156.

${ }^{26}$ This and the following, Op. cit., 16.

${ }^{27}$ Op.cit., 16.

${ }^{28}$ This and the following, Johannessen, 'Årdal Kobberverk', 96, 97.

29 'Relation' (report) to von Løvendahl, 10 March 1712, The National Archives of Norway, Oslo.

(Rentekammeret, Realistisk ordnet avdeling, Bergverksvesen, box 31).

${ }^{30}$ This was explained by the other officials in the report mentioned above.

${ }^{31}$ Copy of letter from the supervisor Georg Mattias Schmidt 9 September 1713, in a letter from von Schört 20

January 1714, the National Archives of Norway, Oslo (Rentekammeret, Realistisk ordnet avdeling,

Bergverksvesen, box 31).

${ }^{32}$ Laudan, From Mineralogy to Geology, 54. It was not before the middle of the eighteenth century, with the founding of mining academies, that mineralogy acquired some sort of scientific understanding.

${ }^{33}$ Registration 17 and 18 April 1720, the National Archives of Norway, Oslo (Rentekammeret, Realistisk ordnet avdeling, Bergverksvesen, box 30).

${ }^{34}$ Pagel,'Paracelsus, Theophrastus Phillipus Aureoles Bombastus Von Hohenheim'.

${ }^{35}$ Johann Heinrich von Schört, letter to the treasury, 27 July 1715, the National Archives of Norway, Oslo

(Rentekammeret, Realistisk ordnet avdeling, Bergverksvesen, box 31).

${ }^{36}$ Debus, The Chemical Philosophy, 2.340.

${ }^{37}$ Ibid.,1.93-95.

${ }^{38}$ Escholt, Geologia Norvegica.

${ }^{39}$ Rössler, Speculum metallurgice politissimum 23, ch. 41.

${ }^{40}$ Ibid., unpaginated supplement ('Bergmännische Termini und Redens-Arten').

${ }^{41}$ von Schönberg, Ausführliche Berg-Information, 109.

${ }^{42}$ Manu Script von berghwergken, Deichmann library, Oslo, fol 38.

${ }^{43}$ Johannessen, 'Årdal Kobberverk', 98.

${ }^{44}$ Holm, Danmark-Norges historie 1720-1814, vol 1 1720-1730, 242-243.

${ }^{45}$ Ibid., 99.

${ }^{46}$ Mokyr. The Enlightened Economy. An Economic History of Britain 1700-1850, 30-40.

${ }^{47}$ Johannessen, 'Årdal Kobberverk', 117, 118.

${ }^{48}$ Worm, quoted in Johannessen, 'Årdal Kobberverk', 130.

${ }^{49}$ Letter from von Schört 26 August 1715, the National Archives of Norway, Oslo (Rentekammeret, realistisk ordnet avdeling, Bergverksvesen, box 31) .

${ }^{50}$ Bruland, British technology \& European industrialization.

${ }^{51}$ Johannessen, ’Årdal Koberverk', 132, 133.

${ }^{52}$ Olsen, 'Nogle Synspunkter for dansk merkantilistisk Erhvervspolitik.'

${ }^{53}$ Johannessen, 'Årdal Kobberverk', 134.

${ }^{54}$ Worm, quoted in Johannessen, 'Årdal Kobberverk', 137.

${ }^{55}$ This and the following from Johannessen, 'Årdal Kobberverk', 137, 138.

${ }^{56}$ Johannessen,'Årdal Kobberverk', 140. 
${ }^{57}$ Op. cit., 141.

${ }^{58}$ Moen, Kongsberg Sølvverk, 126.

${ }^{59}$ Norges geologiske undersøkelser, Report no. 1560/9D, 14 and 25.

${ }^{60}$ Johannessen, ‘Årdal Kobberverk’, 166,167.

${ }^{61}$ Op. cit., 168, 169.

${ }^{62}$ Brealey, 'The Charitable Corporation for the Relief of Industrious Poor'.

${ }^{63}$ Johannessen, 'Årdal Kobberverk', 169.

${ }^{64}$ Morton, "The Rise of the Modern Copper and Brass Industry", 137.

${ }^{65}$ Johannessen, 'Årdal Kobberverk', 170.

${ }^{66}$ Ibid.

${ }^{67}$ Morton, "The Rise of the Modern Copper and Brass Industry", 340.

${ }^{68}$ Johannessen, ‘Årdal Kobberverk', 173.

${ }^{69}$ Op. cit., 174.

${ }^{70}$ Ibid.

${ }^{71}$ Johan Dahl, quoted in Johannessen, ‘Årdal Kobberverk’, 174.

${ }^{72}$ Op. cit., 175.

${ }^{73}$ Op. cit., 179.

${ }^{74}$ Op. cit., 175 .

${ }^{75}$ Op. cit., 177, 179.

${ }^{76}$ Norges geologiske undersøkelser, Report no. 1560/9D, 25.

${ }^{77}$ Lindqvist, "Technology on Trial", 291-307.

${ }^{78}$ Bruland, British technology \& European industrialization, 3-6.

${ }^{79}$ Mokyr, The Enlightened Economy, 60.

${ }^{80}$ Johannessen, 'Årdal Kobberverk', 184.

\section{References}

\section{Archival Sources}

The National Archives of Norway, Oslo, Rentekammeret, Realistisk ordnet avdeling, Bergverksvesen, box 30 and 31 .

Deichmann library, Oslo, fol 38, Manu Script von bergwergken.

\section{Literature}

Berg, Bjørn Ivar. Gruveteknikk ved Kongsberg Sølvverk 1623-1914, vol 1 (Kongsberg: 1994).

Berg, Bjørn Ivar. 'Plikt eller marked i jernverkenes trekullforsyning,' Fortuna (2003): 17-25.

Brealey, Peter. 'The Charitable Corporation for the Relief of Industrious Poor: Philanthropy, Profit and Sleaze in London, 1707-1733,' History. The Journal of the Historical Association, 98, no 333 (December 2013): 708-729.

Bruland, Kristine. British technology \& European industrialization: the Norwegian textile industry in the mid nineteenth century (Cambridge: Cambridge University Press, 1989).

Debus, Allen G. The Chemical Philosophy: Paracelsian Science and Medicine in the Sixteenth and Seventeenth Centuries, (New York: Neale Watson Academic Publications, 1977). 
Dyrvik, Ståle, ed. Norsk фkonomisk historie 1500-1970, vol I 1500-1850 (Bergen: Universitetsforlaget, 1979).

Escholt, Mikkel Pederssøn, Geologia Norvegica, (Christiania,1657) ; Michael Peterson Escholt, Geologia Norvegica, trans. Daniel Collins (London, 1663).

Evans, Chris and Olivia Saunders, 'A World of Copper: Globalizing the Industrial Revolution, 1830-70', Journal of Global History 10, no 1, (2015): 3-26.

Fink-Jensen, Morten. 'Alchemy in Denmark', in Western Esotericism in Scandinavia, eds. Henrik Bogan and Olav Hammer (Boston: Brill, 2016).

Hamilton, H. English Copper and Brass Industries to 1800, $2^{\text {nd }}$ ed (London: Frank Cass \& co, 1967).

Heckscher, Eli. Sveriges ekonomiska historia från Gustav Vasa 1,2 (Stockholm: Albert Bonniers förlag, 1936).

Helland, Amund. Norsk bergret: med udsigt over andre lands bergvarkslovgivning (Kristiania: Aschehoug, 1892).

Holm, Edvard. Danmark-Norges historie 1720-1814, vol 1 1720-1730 (Copenhagen: 1891).

Johannessen, Finn Erhard. ‘Årdal Kobberverk: En industribedrift i et før-industrielt samfunn’ (master's thesis, University of Oslo, 1983).

King, Peter W. 'Sir Clement Clerke and the adoption of coal in metallurgy', Transactions of the Newcomen Society, 73, (2001-02): 33-52.

Laudan, Rachel. From Mineralogy to Geology: The Foundations of a Science 1650-1830 (Chicago: The University of Chicago Press, 1987).

Lindqvist, Svante "Technology on Trial. The Introduction of Steam Power Technology into Sweden, 1715 1736” (PhD diss.,Uppsala University, 1984).

Moen, Kristian. Kongsberg Sфlvverk 1623-1957 (Kristiansand: Sølvverksmuseets venner, 1978).

Mokyr, Joel. The Enlightened Economy. An Economic History of Britain 1700-1850 (New Haven and London: Yale University Press, 2009).

Morton, John “The Rise of the Modern Copper and Brass Industry in Britain 1690-1750" (PhD diss., University of Birmingham, 1985).

Newell, Edmund,'"Copperopolis": the rise and fall of the copper industry in the Swansea district, 1826-1921', Business History, 32 no 3 (1990): 75-97.

Norges geologiske undersøkelser. Report no. 1560/9D, Årdalområdets kopperforekomster, Sogn og Fjordane, 1976-77.

Olsen, Albert, 'Nogle Synspunkter for dansk merkantilistisk Erhvervspolitik,' Scandia vol 3, (1930): $223-273$.

Pagel, Walter, 'Paracelsus, Theophrastus Phillipus Aureolus Bombastus Von Hohenheim,' Complete Dictionary of Scientific Biography (internet).

Rössler, Balthasar. Speculum metallurgia politissimum oder Hell-polierter Berg-Bau-Spiegel (Dresden, 1700).

Von Schönberg, Abraham. Ausführliche Berg-Information (Leipzig, 1673).

Øisang, Ole. Røros kobberverks historie (Trondheim, 1942).

Text to illustration: 
The entrance to one of the lower mines which are situated in a steep cliff. According to von Schört this cliff consisted of layers with cobalt-led at the top followed by tin, copper, silver and gold. Photo 1980: Bjørn Ivar Berg/the Norwegian Mining Museum. 